Relations industrielles

Industrial Relations

\title{
Cyclical Instability in Residential Construction in Canada, by Joseph H. Chung, Ottawa (Economic Council of Canada, 1976), 139 pp.
}

\section{Joseph B. Rose}

Volume 32, numéro 2, 1977

URI : https://id.erudit.org/iderudit/028794ar

DOI : https://doi.org/10.7202/028794ar

Aller au sommaire du numéro

Éditeur(s)

Département des relations industrielles de l'Université Laval

ISSN

0034-379X (imprimé)

1703-8138 (numérique)

Découvrir la revue

Citer ce compte rendu

Rose, J. B. (1977). Compte rendu de [Cyclical Instability in Residential Construction in Canada, by Joseph H. Chung, Ottawa (Economic Council of Canada, 1976), 139 pp.] Relations industrielles / Industrial Relations, 32(2), 287-288. https://doi.org/10.7202/028794ar

Tous droits réservés @ Département des relations industrielles de l'Université Laval, 1977
Ce document est protégé par la loi sur le droit d'auteur. L’utilisation des services d’Érudit (y compris la reproduction) est assujettie à sa politique d'utilisation que vous pouvez consulter en ligne.

https://apropos.erudit.org/fr/usagers/politique-dutilisation/ 
comptent travailler avec des sujets humains sont claires: l'intérêt du sujet prime tout. Dans tous les cas, lui-même ou un représentant autorisé doit consentir explicitement à participer à une recherche, sans contrainte aucune et en pleine connaissance de cause et en tout temps, il doit pouvoir se désister si tel est son désir. Des règles strictes doivent s'appliquer pour assurer l'anonymat et la confidentialité au sujet participant et le chercheur doit se faire un devoir de respecter l'intimité de ceux dont il requiert la collaboration. Les notions d'intimité, d'anonymat s'interprètent toujours du point de vue du sujet et non de celui de l'observateur, surtout dans les cas où l'enquêteur considère une population d'une culture différente de la sienne.

Ces règles déontologiques doivent guider le chercheur au moment de la conception de son projet et au moment de la rédaction de la demande de subvention. Sa demande sera préalablement soumise à un comité d'évaluation, dont le Conseil suggère la formation dans chacun des établissements universitaires qui l'examinera à la lumière des règles déjà énoncées; le comité pourra refuser un projet, demander des modifications ou encore demander des rapports périodiques au chercheur pour pouvoir suivre le déroulement de son travail.

Toutefois l'objectif qu'entend poursuivre le Conseil n'est pas tant de soumettre les chercheurs à des règlements rigides que de les amener à prendre conscience des exigences éthiques de leurs activités et à s'y soumettre spontanément. Parmi les moyens d'atteindre cet objectif, il y a sûrement la diffusion la plus large possible du rapport du groupe consultatif de déontologie; nous suggérions aussi que le Conseil prépare un dossier qui présente des exemples de cas soumis aux comités d'évaluation et qui peuvent servir à guider les réflexions des chercheurs. Une autre suggestion serait de s'interroger sur la formation déontologique des chercheurs en sciences humaines; dans la mesure où les établissements d'enseignement avancé ne sensibilisent pas leurs étudiants à ces questions, la tâche du Conseil sera beaucoup plus grande.

\section{Université Laval}

Gilles DUSSAULT

Cyclical Instability in Residential Construction in Canada, by Joseph $\mathrm{H}$. Chung, Ottawa (Economic Council of Canada, 1976), 139 pp.
This is another in the series of studies produced for the Economic Council of Canada's Reference on Construction Instability in Canada. Its main purpose is to assess some of the causes and effects of cyclical instability in residential construction in Canada and suggest measures for creating greater stability in housing construction.

One might ask, why study instability in the residential sector? A major reason is that the residential sector accounts for a disproportionate share of instability in the construction industry. Fluctuations in housing activity tend to create inefficiencies in both product and labour markets and thus contribute to the rise in housing costs.

The book is divided into five chapters. In Chapter 1 , the author provides an overview of the meaning and dimensions of instability and introduces numerous measurements of the business cycle. The interaction of general business cycles and housing-start cycles are discussed in detail. A major finding is that housing activity "varies considerably from one dwelling type to another, from one region to another, and from one period to another'. Because of these wide cyclical fluctuations, the formulation of national policy requires a careful analysis of disaggregated data.

Chapter 2 discusses the determinants of residential construction activity. The analysis of long-run growth in dwelling units considers the influence of demographic factors, and income, price, and credit variables. Cyclical fluctuations are assessed in terms of the availability of mortgage funds, interest rates and monetary policy. The author cogently points out that current views and previous empirical analyses of the determinants of residential construction are not in agreement regarding the relative influence of these factors.

The next two chapters of the book are more technical. An econometric model of cyclical instability is developed and the results are presented. In Chapter 5 the author considers the arguments - both pro and con - for stabilizing residential construction and considers alternative directions for policy makers. He concludes that there is a need to produce greater stability in residential construction and that efforts should be made to insulate the residential sector from monetary policy.

This book is well organized and should prove to be a valuable reference volume. It is likely to be of interest to academics, government officials and practitioners in financial institutions and the housing in- 
dustry. Those who are squeamish about quantitative methods should be forewarned that this is not an easy book to read.

\section{Joseph B. ROSE}

School of Administration

University of New Brunswick

The Development of an African Working Class, by R. Sandbrook and R. Cohen, Toronto, University of Toronto Press, 1976, $330 \mathrm{pp}$.

C'est un colloque tenu à l'Université de Toronto en avril 1973 qui fut l'occasion de la présentation des textes réunis sous ce titre. Les auteurs se sont interrogés sur l'émergence d'une classe ouvrière africaine et sur les voies d'un changement de la condition des travailleurs sur le continent africain: ce changement est-il mieux garanti par la réforme ou par la révolution? Question ancienne, souvent reformulée depuis deux siècles par ceux qui ont souhaité des changements sociaux, qui ici est posée dans un contexte géographique et social différent.

La presque totalité de ceux qui ont contribué à ce recueil postulent que les sociétés africaines doivent changer et que ce changement doit se faire dans le sens de l'égalitarisme, donc de l'éradication du colonialisme et du racisme. Là où l'accord est plus difficile, c'est sur les moyens d'y parvenir: changement progressif, changement radical, modèle capitaliste, modèle socialiste, etc...?

Le lecteur ne trouvera pas de réponses définitives dans cet ouvrage; il pourra cependant documenter ses questions en prenant connaissance d'analyses d'historiens et de sociologues sur les premiers développements d'une conscience de classe ouvrière en Afrique, sur les organisations de travailleurs ainsi que sur les pratiques ouvrières contemporaines. Les éditeurs présentent des études de cas menées dans divers pays, en particulier au Nigéria, au Kénya, au Sénégal, au Ghana et en Tanzanie, dont l'expérience socialiste fait l'objet de deux articles. Une bibliographie de titres choisis accompagne la douzaine d'articles de ce recueil, à l'intention de ceux qui voudraient en savoir plus sur l'organisation ouvrière en Afrique.

Gilles DUSSAULT

Université Laval
The Worker and the Job, The American Assembly, by Jerome M. Rosow, Ed., N. J. Englewood Cliffs, Prentice Hall, $1974,208 \mathrm{pp}$.

Dans ce volume, sept (7) experts se penchent sur le travailleur américain et le monde du travail. Le fruit de leurs réflexions, recherches et expériences est rapporté en trois (3) parties qui ont comme titre: «Overview», «Contemporary Issues» et «New Horizons».

Tel que nous l'indique son titre, la première partie donne un aperçu général de la situation tant sur le plan sociologique qu'économique. Elle est divisée en deux chapitres intitulés "The Meaning of Work " et «The Changing American Economy».

Le premier chapitre, écrit par Daniel Yankelovich, est une réflexion sur la signification du travail. Après avoir tracé les origines de l' "American Work Ethic", l'auteur s'attarde à donner ses composantes essentielles dans les années 60. Il examine ensuite les principaux changements susceptibles de modifier la façon de concevoir le travail, à savoir la nouvelle définition du succès, la réduction de la peur de l'insécurité économique, la nouvelle division du travail entre les sexes, l'augmentation des attentes et la désillusion à l'égard du culte de l'efficacité. Toutefois selon Yankelovich, ces transformations n'atteignent pas tous les travailleurs également. Trois (3) groupes sont en fait plus particulièrement touchés: les jeunes instruits, les jeunes non instruits et les femmes. La réaction de ces groupes est un bon indicateur de ce que sera l'attitude future vis-à-vis le travail.

Dans le deuxième chapitre, Eli Genzberg nous fournit les principales données statistiques au sujet de la main-d'œuvre et des emplois. Comme il le souligne luimême, son but n'est pas de prouver ou de rejeter une théorie mais simplement de donner un cadre de référence, soit la comparaison et l'évolution entre les années 20 et 70. Ginzberg s'aventure toutefois à faire quelques projections dans le futur.

La deuxième partie du volume "Contemporary Issues» débute par un article de George Strauss sur les travailleurs, leurs attitudes et leurs adaptations. Il attire notre attention sur les questions suivantes: Jusqu'où les travailleurs sont-il insatisfaits? Cette insatisfaction est-elle essentiellement due au travail répétitif et monotone ou a-t-elle aussi pour cause les salaires, la supervision ou l'absence de mobilité? Estce que cette insatisfaction augmente? 